\title{
Additional Benefits of Community Managed Forest: A Case Study of Champadevi Community Forest
}

\author{
Bhanu B. Panthi \\ Department of Geography, University of Leicester, UK \\ e-mail: panthibrb@gmail.com
}

\begin{abstract}
This research attempts to identify the existing condition of the community managed forest based on the assumption that it will serve as a proxy for the condition of other forests in the mid hills region of Nepal. The research area has an atypical variation in altitude and diverse pattern of vegetation. This study mainly focuses on estimating carbon content in the forest and identifying the species that has more carbon storage capacity. The research signifies the role of forests in mitigation of 'Global warming' and 'Climate change' by storing carbon in tree biomass. These types of community based forest management programs are significant for their additional carbon sequestration through the avoidance of deforestation and degradation. The carbon sequestration have a significant contribution to environmental benefits, any shrinkage of forests have an enormous impact on $\mathrm{CO} 2$ emission with long term consequences. Thus, the development and expansion of community managed forests provide many benefits to the adjacent community and globally at large.
\end{abstract}

Key words: carbon forestry, carbon sequestration, climate change, global warming, sustainable forest management

\section{Introduction}

In recent years the problem of forest degradation, has been recognized across the globe. At the same time there is a general acceptance of the numerous benefits of the forests. Thereby governments, in an attempt to tackle the problem of deforestation and maximize the benefits associated with the forests are handing forest areas to local communities under a scheme of 'Community Forest Management'. The scheme is already in practice in Burkina Faso, Cameroon, India, Mexico, Papua New Guinea, Peru, Tanzania, Nepal, and many other part of the world. It is estimated that 'around $14 \%$ of all forest in developing countries are under CFM today, three times more than 12 years ago' (White \& Martin 2002).

Community forest plays an outstanding role in Nepal. It involves forest upkeep by the community thereby improving the forest condition as well as alleviating poverty through inter linkage of forest, agriculture and livestock. Local and indigenous communities rely on the forests for food, clean water, medicines, firewood and timber. In 1978, the World Bank conducted the assessment of forestry in Nepal and approved the theory of 'Himalayan degradation' and recommended the 'Rural Energy Crisis' and 'Ecology Crisis'. Both these recommendations involved massive afforestation programs (World Bank 2008). Consequently, the Government of Nepal realized the importance of local people involvement in the protection and management of forest resources thus the government-sanctioned programs turnover management of national forests to village users, called 'user-groups'. However, the performance of community forest is not yet under clean development mechanism. The estimation and valuation 
of carbon content in any community forest system is very important. If community forests of Nepal are included in the 'Kyoto protocol' under CDM, surrounding communities will be able to generate a certain amount of income from them. Under this mechanism, forest managed through the participatory approach will get income through carbon trading. As far as community forest is concerned globally, there are still await answer about community forest as climate mitigation option. In this view, this paper will address additional significance of community forestry in reducing global carbon emission, carbon capture of individual species and other additional benefits.

\section{Methodology}

The study was carried out during July and August, 2010 in Champadevi Community Forest, which lies in the Chandragiri hill, $12 \mathrm{~km}$ in N-W direction from Kathmandu. This is a catchments basin for Panighat khola and Matatirtha khola toward Kathmandu valley.

Line Transect Method and quadrate size $20 \times 20 \mathrm{~m}^{2}$ was used for sampling. As forest elevation ranges from $1,400 \mathrm{~m}$ to $2,300 \mathrm{~m}$, the stratification transect was made for every $100 \mathrm{~m}$ difference and nine consecutive contours were formed using GPS. The first quadrate was located at a distance of $100 \mathrm{~m}$ from the westward boundary of the forest at $1500 \mathrm{~m}$ elevation. To estimate the biomass of the trees within the quadrate, diameter at breast height $(\mathrm{DBH})$ i.e. $1.3 \mathrm{~m}$ from the ground of the trees species were noted and diameter with less than $5 \mathrm{~cm}$ diameter were excluded. In the $1,500 \mathrm{~m}$ elevation, second quadrate was located at same line $100 \mathrm{~m}$ apart from first plot and the diameter was measured. Similarly, another plot was fixed and diameter was measured. Consequently in the next $1,600 \mathrm{~m}, 1,700 \mathrm{~m}, 1,800 \mathrm{~m}$, 1,900m, 2,000m, 2,100m, 2,200m and 2,300m similar procedure was applied to make 27 plots in total which represent the sampling plot at the each elevation of the forest. Necessary information and relevant reports were consulted from the forest users groups.
The biomass of each tree species in each quadrate was determined with the help of guideline prepared by Government of Nepal, Ministry of Forest, and Soil Conservation, Department of Forest (DoF) and Natural Resource Management Sector Assistance Program (NARMSAP), which is a simplified equation that requires only $\mathrm{DBH}$ as single input variable to calculate biomass of foliage, branch and stem.

Regression model is

Ln $\mathrm{W}=\mathrm{a}+\mathrm{b}$ X Ln $(\mathrm{DBH})$. i

(NARMSAP 2000)

Where,

$\mathrm{W}=$ Green weight of tree component (biomass) in kilogram.

$\mathrm{a}=$ intercept

$\mathrm{b}=$ slope

$\mathrm{DBH}=$ Over bark diameter of the tree at breast height (measured at 1.3 meter above ground) in centimeter.

\section{Results and Discussion Characteristics of vegetation and carbon content}

The community forest can be divided into three sections. At the lowest altitude (1400-1800 m) Pinus roxburghii was the dominant specie among the trees. The other tree species were Pinus species, Schima wallichi, and Alnus nepalensis. At mid altitude (1800$2100 \mathrm{~m}$ ), the forest can be characterized between a mixed broadleaf forest where the dominant specie was Pinus and the rest as Rhodendendron arboreum, Alnus nepalensis, Quercus floribunda, Quercus glauca. Similarly, at the highest altitude (2100-2300m) mature trees were dominated by Quercus glauca and other species found within that range were Quercus floribunda, Celtis australis, and Alnus nepalensis. A total of 19 species were recorded in plots of $\left(20 \times 20 \mathrm{~m}^{2}\right)$ at each contour at an elevation of $100 \mathrm{~m}$ in the altitude range from 1400 to $2300 \mathrm{~m}$. The most widespread species were the Pinus roxburghii in 24 plots, followed by the Alnus nepalensis in 21 plots and Schima wallichi in 18 plots. The rarest species was Myrica esculenta found in 3 plots.

Table 1. Percentage distribution of tree DBH in Champadevi Community Forest, Nepal

\begin{tabular}{c|c|c|c|c|c|c}
\hline $\begin{array}{c}\text { DBH class } \\
(\mathrm{cm})\end{array}$ & $5-10 \mathrm{~cm}$ & $11-20 \mathrm{~cm}$ & $21-30 \mathrm{~cm}$ & $31-40 \mathrm{~cm}$ & $41-50 \mathrm{~cm}$ & $>50 \mathrm{~cm}$ \\
\hline Percentage & $51.35 \%$ & $36.5 \%$ & $8.2 \%$ & $2.35 \%$ & $0.9 \%$ & $0.7 \%$ \\
\hline
\end{tabular}


Bhanu B. Panthi/Additional Benefits of..........

This table shows that more than $50 \%$ of the tree species have the DBH range (5-10) $\mathrm{cm}$, which indicates that the forest is young. The species distribution primarily consists of small sized trees with a diameter range of $5-20 \mathrm{~cm}$. There is a very low percentage of tree species with a diameter exceeding $40 \mathrm{~cm}$. The middle part $(1800 \mathrm{~m}-2100 \mathrm{~m})$ of the forest shows smaller DBH as compared to the lower and higher altitude. The few trees in the highest altitude in mixed broadleaf forest have DBH greater than $50 \mathrm{~cm}$.
The study mainly focused on the carbon content in the forest biomass which was found to be $29.980 \mathrm{t} \mathrm{C} /$ ha. Highest carbon stock $\left(5.47 \mathrm{~kg} / \mathrm{m}^{2}\right)$ was found at the highest altitude $(2300 \mathrm{~m})$. Carbon stock was higher at the lowest altitude $\left(5.08 \mathrm{~kg} / \mathrm{m}^{2}\right)$ than at the middle altitude $1.64 \mathrm{~kg} / \mathrm{m}^{2}$ (See figure 1). Interestingly, at the middle altitude (1800-2100) the value of carbon content approximately remained constant.

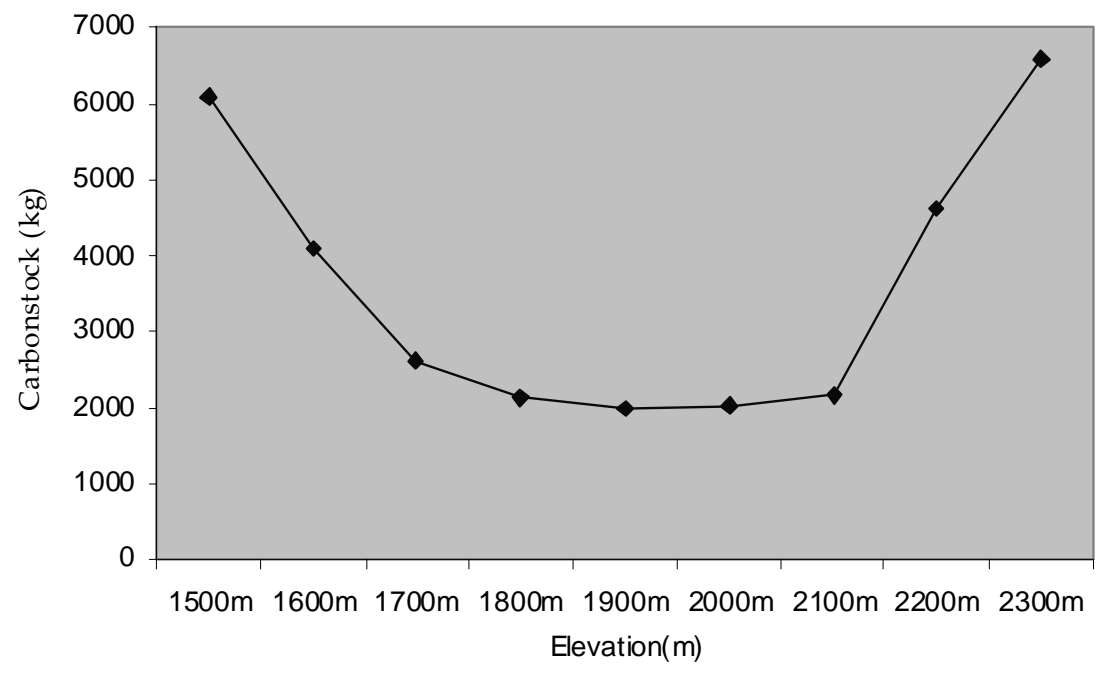

Fig. 1. Carbon stock in tree biomass (kg) at different elevation (m)

Among all the species in the forest, Myrica esculenta has the lowest carbon content (28 kg) and the Quercus floribunda has the highest carbon content (7219 kg) followed by Pinus roxburghii $(5528 \mathrm{~kg})$, Quercus glauca (4512 kg), Pinus sps. (2340 kg) (Appendix 1). Quercus floribunda and Quercus glauca higher carbon content indicate their greater potential for carbon capture. The low altitude (1500-1800m) dominated by pine forest had a carbon stock of 31.19 tC/ha. However, the high altitude (1800-2300m) characterized as mixed forest had a carbon stock of $29.01 \mathrm{tC} / \mathrm{ha}$.

\section{Additional Benefits of Community Managed Forest}

Reduction in forest degradation \& deforestation Past experience indicates that many communities in the developing world have applied 'Community Based Forest Management’ (CBFM) programs and policies.
This study reveled that, this kind of practices results in additional carbon sequestration through reduced emissions from deforestation. In the present case study of Champadevi 'severely degraded forest was handed to community and protected by strict protected measures' (FUG discussion). This forest is seen as resource [fuel wood, timber/pole/wooden pluck, grass/Fodder, NTFPs], which contributes in numerous ways to the livelihoods of all the members in FUG (Panthi, 2010). Moreover, payments as a result of carbon services might have a bigger impact through the provision of incentives for communities to further expand community managed forest. This program serves sustainability and provides income generating opportunities for poor communities. This sort of management could provide an opportunity cost of keeping forest as forest; through plantation where the areas are likely to be deforested (Skutseh, 2006). 


\section{Additional carbon sequestration through increase in tree biomass}

It was achieved with several decades of experimentation in forest protection and significant paradigm change by Forest Users Groups (FUGs). In the current study, low altitude pine forest was planted by community. The low altitude dominated by pine forest had a carbon stock of $31.19 \mathrm{tC} / \mathrm{ha}$ and the high altitude characterized as mixed forest had a carbon stock of $29.01 \mathrm{tC} / \mathrm{ha}$. FUGs are the grass root players to change and should be benefited from carbon trading for avoiding deforestation and enhancement of tree biomass through plantation. According to Dahal (2003) imposed that if one hector of community forest sequesters one ton additional carbon per year, it can earn net 1 dollar/ha/yr by our country (Nepal). Dahal (2003) estimation if one dollar is added as reward to any community forest one ton carbon/ha/yr, the total of 10 million hector community forest can earn 10 million dollar per year. This scheme is likely to reduce the deforestation and enhance the community managed forest and capture more carbon.

\section{Identification of more carbon sequestrating species}

In the present case study, Quercus floribunda, Quercus glauca and Pinus roxburghii have the higher carbon capture potential. The pine plantation have total carbon stocks of $31.19 \mathrm{tC} / \mathrm{ha}$. This plant species could be useful for the carbon capture projects. A similar study carried out in Miyun watershed (China) showed that pine forest (Pinus roxburghii) has greater carbon storing and sequestering capacity than other forest (Jianmin \& Zhing 2007). Mostly, in case of Nepal in mid hill regions, pine forest provides biomass fuel energy to substitute fossils fuels. This might be a better options and cost effective way to reduce global carbon emission through fossils fuels. This supports to the idea of Pacala and Socolow (2004) earlier finding that forest, forestry and forest products cannot solve the entire problem of climate change but could be an essential piece to a comprehensive climate strategy.

Local initiatives for protection and conservation In the present case study, ecological diversity [birds, deer, fox, and tiger] and environmental services [springs, forest cover, and natural hiking] are better after handed to the community. 'Deforestation and forest degradation has been stopped through strict protective measures' (FUG discussion, Panthi 2010). In my study the local community groups emphasized the importance of community forests being economic friendly first to have any environmental sense making for the local community. The present study supports Skutcsh (2006) earlier findings about the significance of opportunity costs for the local communities with regard to conservation work. The Stern Review (2006) reinforces the finding that forest conservation; afforestation, reforestation and sustainable forest management can provide up to $25 \%$ of emission reduction needed to combat climate change effectively.

\section{Payment to Ecosystem services: A Win-win strategy for Sustainable Development through Carbon Forestry}

Since traditional forest management philosophy has already faded away, a multipurpose forest management viewpoint is flourishing which reflects; ecological, economical and social concerns. This research signifies forest resources [timber production, consumption of fuel wood for cooking] as social and economic concerns. It has some environmental benefits [increase in biodiversity, sources of water, recreational value] to the FUG in Champadevi. This support to the idea of Nelson and De Jong (2003) for social, economical and environmental reasons, it would be best to support 'Community Forestry Program'.

In addition to these economic roles community forestry can provide broader role in carbon mitigation which is valuable in itself. It has a global role in curtailing the process of deforestation, degradation and carbon sequestration. Clearly, contribution of community forest could meet the binding target of emission reduction of Kyoto Protocol (Gundimeda, 2004). The payment thus generated ecosystem services through carbon trading compensated the community forest user groups in the developing countries to engage in conservation of forest.

In the end a positive link between community forestry and the overall value of the forest includes both its environmental value and its economic value. Furthermore, both these values reinforce each other in the context of community forestry. Giving communities ownership of their forests motivate and empower them resulting in a far greater effort on their part to conserve forest 
and use them in a sustainable manner thereby enhancing a forest's capacity to act as a carbon sink along with other environmental benefits. Similarly, this research suggests reduction in deforestation and forest degradation increase in carbon sequestration and increase in income for the local communities. Protection of forest results in improvement in both the quality and size of the area covered, which in turns results in a large carbon sink. Hence, payment for environmental services can play an immense role in reducing the effects of 'Global Climate Change' through the conservation of forest and improving the livelihood of the community through incentives thus generated. This leads to believe the practices of community forest, in which sustainable development might be achieved through local people management and contribute especially to environmental values as well as income generating opportunities.

\section{Acknowledgements}

I would like to express my sincere gratitude to Dr. Joerg Kaduk and Dr Sue Page for their noble guidance. I am indebted to the Department of Geography, University of Leicester for technical support during the research. Also, coordination and support from Ministry of Forest/DoF/GoN, and Forest User Group, Champadevi highly acknowledged.

\section{Appendix}

\section{Carbon stocks and species density}

\begin{tabular}{|c|c|c|c|}
\hline Local name & Scientific name & Carbon content (Kg) & Species density (ind/m2) \\
\hline Sallo & Pinus roxburghii & 5528 & 0.0354 \\
\hline Patale sallo & Pinus sps. & 2340 & 0.0256 \\
\hline Uttis & Alnus nepalensis & 1976 & 0.0194 \\
\hline Phalant & Quercus glauca & 4512 & 0.0182 \\
\hline Seto kharsu & Quercusfloribunda & 7219 & 0.0123 \\
\hline Khari & Celtis australis & 3342 & 0.0098 \\
\hline Faledo & Erithrina stricta rox. & 219 & 0.0014 \\
\hline Ipil ipil & Lecaena leucocephala & 720 & 0.0043 \\
\hline Jhingane & Eurya accuminata & 256 & 0.0032 \\
\hline Kathe kaulo & Machilus gamblei & 176 & 0.0005 \\
\hline $\begin{array}{l}\text { Kafal } \\
\text { Painyu }\end{array}$ & $\begin{array}{l}\text { Myrica esculenta } \\
\text { Prunus cerasoides }\end{array}$ & $\begin{array}{l}28 \\
135\end{array}$ & $\begin{array}{l}0.0001 \\
0.0002\end{array}$ \\
\hline Seti kath & Myrsine capitellanta & 492 & 0.0015 \\
\hline Myal & Pyrus pashia & 145 & 0.0004 \\
\hline Laliguras & Rhodendendron arboreum & 97 & 0.0002 \\
\hline Hade bayar & Zizyphus incurva & 112 & 0.0004 \\
\hline $\begin{array}{l}\text { Chilaune } \\
\text { Bhalayo } \\
\text { Arkhalo }\end{array}$ & $\begin{array}{l}\text { Schima wallichi } \\
\text { Rhus wallichi } \\
\text { Oercus spicata } \\
\text { Total }\end{array}$ & $\begin{array}{l}4296 \\
212 \\
824 \\
32629\end{array}$ & $\begin{array}{l}0.0163 \\
0.0012 \\
0.0082\end{array}$ \\
\hline
\end{tabular}




\section{References}

Dahal, N. 2003. Bishwa lai nai Samudaik Ban ko Yogdan, Himal News Paper 2060, Kartik, 16-30.

Gundimeda, H. 2004. How 'Sustainable' is the sustainable development objective of CDM in developing countries like India? Forest Policy and Economics 6(3-4): 329-343.

Jianmin, X., and W. U Zhing. 2007. Economic Benefit Analysis of Carbon Sequestration of Five Typical Forest Types in Beijing Miyun watershed. Chinese Forestry Science and Technology.6(1). pp. 57-61.

Nelson, K.C. and B. H. De Jong. 2003. Making global initiatives local realities: carbon mitigation projects in Chiapas, Mexico. Global Environmental Change 13: 19-30.

Pacala, S. and R.Socolow. 2004. Stabilization Wedges: Solving the Climate Problem for the Next 50 Years with Current Technologies. Science 305:968-972
Panthi, B. B. 2010. Prospect of reducing carbon emission through community forestry management: a case study of Champadevi in Nepal, MSc dissertation, University of Leicester, Leicester, UK.

Skutsch, M. 2006. The rationale for carbon crediting for community forest management. In Skutsch (Ed.) Can Carbon Income Combat Forest Degradation, Rational and Case Studies. Technology and Sustainable Development, University of Twente, the Netherlands.

Stern Review. 2007. Stern Review on the Economics of Climate Change, pre-publication edition. Cambridge: Cambridge University Press.

White, A. and A. Martin. 2002. Who owns the world's forests? Forest Trends and Center for International Environmental Law, Washington, DC.

World Bank. 2008. a. Press Release No: 2009/029/SDN. Retrieved September 2, 2010 from http:// web.worldbank.org/WBSITE/EXTERNAL/ NEWS. 